\title{
The effect of supply chain integration on customer loyalty: The mediating roles of operational performance and customer satisfaction
}

\author{
Sudirman Zaid $^{a^{*}}$, Alida Palilati ${ }^{\mathrm{a}}$, Rahmat Madjid ${ }^{\mathrm{a}}$ and Sarini Yusuf Abadi ${ }^{\mathrm{b}}$
}

${ }^{a}$ Departement of Management, Halu Oleo University, Indonesia

${ }^{b}$ Departement of Fisheries, Halu Oleo University, Indonesia

\section{H R O N I C L E}

\begin{tabular}{l}
\hline Article history: \\
Received March 10, 2021 \\
Received in revised format May 7, \\
2021 \\
Accepted August 12021 \\
Available online \\
August 32021 \\
\hline Keywords: \\
Supply Chain Integration \\
Operational Performance \\
Customer Satisfaction \\
Customer Loyalty \\
Tuna Fillets SMEs Industries \\
\hline
\end{tabular}

\section{A B S T R A C T}

The objective of the research is to examine the role of Supply Chain Integration (SCI) which consists of; suppliers, customers, and internal integration in building customer loyalty. This study uses data from 308 top managers of Tuna Fillets SMEs Industries in Southeast Sulawesi Province, Indonesia as respondents. The research model was analyzed by using PLS-SEM. The research found that SCI had a significant direct effect on operational performance and customer satisfaction. The research also found that operational performance and customer satisfaction had some impacts on increasing loyalty of Tuna Fillets SMEs Industries customers. The results of the analysis also provide information that operational performance and customer satisfaction can be a mediator of the influence of Supply Chain Integration.

(C) 2021 Growing Science Ltd. All rights reserved.

\section{Introduction}

The development of fishery business activities is currently more directed at efforts to create added value for fishery products through the creation of fisheries-based downstream industries, both small, medium and large scale. This is intended so that in addition to increasing people's income, it is also directed at creating job opportunities which can have an impact on reducing the unemployment rate (Kurnia \& Mallawa, 2021). Tuna Fillets is one of the capture fisheries-based development products that has the potential to be developed because in addition to having a high level of demand, Tuna Fillets are also produced with low production costs and based on Small Medium Enterprises (SMEs), so that this business is expected to be able to provide added value. for the community and can have an impact on increasing welfare and reducing unemployment (Pakiding \& Silamba, 2018; Arthatiani et al., 2020). In Indonesia, Tuna Fillets Industries has been widely developed in coastal areas, especially in the eastern region which has many centers of Tuna Fillets Industries. In general, Tuna Fillets Industries in Indonesia are quite developed. Although the demand is quite high from both end consumers and other industrial consumers, the performance of Tuna Fillets Industries is seen as not optimal. One of these indicators is operational performance which is still relatively low due to an ineffective supply chain. This causes the margin and added value received by business actors is still relatively small. This has resulted in Tuna Fillets Industries not having an impact on improving people's welfare (Prayoga, Iskandar \& Wisudo, 2017; Kurnia \& Mallawa, 2021). Operational performance is largely determined by the effectiveness of the supply chain. The implementation of Supply Chain Integration (SCI) is expected to be able to improve operational performance (Liu, Liu \& Gu, 2021; Hani, 2021; Nartey, Aboagye-Otchere \& Simpson, 2020). If supply chain integration is increased, it will have an impact on increasing operational performance which in turn will have an impact on creating customer satisfaction and loyalty to the products produced. Based on this phenomenon, supply chain integration plays an important role in building and creating customer satisfaction and loyalty. This study aims to examine and determine the impact of supply chain integration in building customer loyalty. In this connection, in this study, operational performance and customer * Corresponding author

E-mail address: sudirmanzaid@gmail.com (S. Zaid)

(C) 2021 Growing Science Ltd. All rights reserved.

doi: $10.5267 /$ j.uscm.2021.8.002 
satisfaction will be used which will act as mediators of the relationship between supply chain integration and customer loyalty. This research was conducted in the center area of Tuna Fillets Industries in Southeast Sulawesi Province, Indonesia.

\section{Literature Review}

\subsection{Supply Chain Integration (SCI)}

Supply Chain Integration (SCI) is defined as connectivity between strategic organizations that are directly related to companies such as; suppliers and customers in a network or partnership format (Tarigan et al., 2021; Shukor et al., 2020; Phan, Doan \& Nguyen, 2020; Munir et al., 2020; Saragih et al., 2020). SCI aims to achieve cost efficiency and provide added value to customers. There are three dimensions of SCI, namely; supplier, customer, and internal integration (Shukor et al., 2020; De Vass, Shee \& Miah, 2018; Jajja, Chatha \& Farooq, 2018). Supplier integration plays a role in the input supply mechanism for the company's production needs. Supplier integration leads to the process of creating cooperation and partnerships between companies and their suppliers in order to obtain input supply efficiency (Zhang et al., 2020; Buzzetto, Bauli \& Carvalho, 2020; Errassafi, Abbar \& Benabbou, 2019; Amoako-Gyampah et al., 2020). Customer Integration refers to the process of creating a harmonious relationship between the company and its customers. Customer integration plays an important role in creating customer value and customer satisfaction (Errassafi, Abbar \& Benabbou, 2019; dos Santos Hentschke, Torres Formoso \& Echeveste, 2020; Jung \& Boo, 2020; Ariadi et al., 2021; Martinelli \& Tunisini, 2019). Internal Integration refers to the coordination mechanism between divisions or departments within the company in order to achieve optimization of production results. Internal integration plays an important role in achieving a match between production performance and marketing performance (Errassafi, Abbar \& Benabbou, 2019; Amoako et al., 2020; Khalaf \& El Mokadem, 2019).

\subsection{Operational Performance $(O P)$}

$\mathrm{OP}$ is seen as the result achieved by carrying out managerial activities from a complex and integrated supply chain which is a combination of various supporting factors in the process of producing goods or services (Lu et al., 2018; Al-Sa'di, Abdallah \& Dahiyat, 2017). Superior OP through the incorporation of various supporting factors will have an impact on cost efficiency (Salam, 2017). In addition, the increase in OP is also intended to achieve effectiveness in an effort to increase the company's revenue and profit (Truong et al., 2017).

Various kinds of OP measurements used by previous researchers, namely; production flexibility, delivery, product quality, and production cost (Chavez et al., 2016); cost, inventory, supply chain cost, responsiveness, and product development (Salam, 2017); delivery, forecasting, lead time, service after sales, and inventory (Acar et al., 2017).

\subsection{Customer Satisfaction (CS)}

Satisfaction is a person's feeling of pleasure or disappointment that arises after comparing expectations with actual (Nunkoo et al., 2020; Paais \& Pattiruhu, 2020). CS is a evaluative assessment of goods or services after they have obtained and used them (Kim, Kim \& Hwang, 2020; Pandey et al., 2020). In recent years, CS has often been the focus of research for academics and marketing practitioners. This is based on the philosophy that to achieve company success, it is very dependent on the ability to create products/services that customers want.

CS has several measurements used by previous researchers, namely; satisfied with firm, thinks good idea, thinks good choice (Lombart \& Louis, 2014); transaction based satisfaction, masing-masing; (a) satisfied with recent transaction process, (b) contented with information provided, (c) satisfied with mechanism, and experience based satisfaction, masing-masing; (a) pleased with experience staying, (b) experience is pleasurable, (c) choice to stay the other attribute (Liang, Choi \& Joppe, 2018).

\subsection{Customer Loyalty (CL)}

CL is a condition where customers or consumers regularly or continue to purchase products with long-term commitments (Pandey et al., 2020). Loyalty is seen as the tendency of customer attitudes and behavior to like one product compared to other products (Le \& Le, 2020; Islam et al., 2021). Loyalty can be shown through the attitude of wanting to consume continuously and maintaining good relationships with sellers. CL is reflected as customers who make purchases continuously not only in terms of consumption, but also recommend the product to others (Ji \& Prentice, 2021; Prasetyo et al., 2021).

CL has several measurements, including: behavioral dimensions, including (a) repeat purchasing, (b) says positive thing, (c) continuing preference for the same service; and attitudinal dimensions, terdiri atas (a) repurchase intention, (b) willingness to recommended to other, (c) demonstrating resistance to switch to competitor (Otsetova, 2017). CL can also be measured using indicators: wish to continue connecting with firm; encourage and relative joint with firm; contain long-term relationship with firm; say positive things of firm (Islam et al., 2021). 


\subsection{SCI and $O P$}

SCI and OP have a conceptual relationship. SCI as supplier, customer and internal integration has a significant direct effect on OP (Ganbold, Matsui \& Rotaru, 2020; Errassafi, Abbar \& Benabbou, 2019; Shou et al., 2018). Good SCI will have an impact on increasing the intensity of positive OP. Several previous researchers have found that SCI has a direct effect on OP (Lu et al., 2018; Errassafi, Abbar \& Benabbou, 2019; Liu, Liu \& Gu, 2021; Hani, 2021; Nartey, Aboagye-Otchere \& Simpson, 2020; Wong, Boon-Itt \& Wong, 2011). Based on the results of these previous studies, the first hypothesis developed in this study is:

$\mathbf{H}_{1 \mathbf{a}}$ : SCI as Supplier has a significant direct effect on OP.

H1b: SCI as Customer has a significant direct effect on OP.

$\mathbf{H}_{1 \mathbf{c}}$ : SCI as Internal has a significant direct effect on OP.

\subsection{SCI and CS}

The SCI practise can also be used to build CS. SCI as supplier, customer and internal integration has a significant direct effect on CS (Yu et al., 2013). Good SCI will be increase CS. For this reason, it is very necessary to manage SCI properly to achieve CS. Several previous researchers found that SCI had a significant direct effect on CS (Yu et al., 2013; Zhao et al., 2013). Based on the previous research, the second hypothesis developed in this study is:

$\mathbf{H}_{\mathbf{2}}$ : SCI as Supplier has a significant direct effect on CS.

$\mathbf{H}_{\mathbf{2 b}}$ : SCI as Customer has a significant direct effect on CS.

$\mathbf{H}_{2 \mathbf{c}}$ : SCI as Internal has a significant direct effect on CS.

\section{7. $O P$ and $C S$}

OP has an key important factor in creating CS. Good operational performance will have an impact on increasing CS. Several previous researchers found the effect of OP on CS (Abdallah, Phan \& Matsui, 2016; Chavez et al., 2016). Based on the previous research, the third hypothesis developed in this study is:

$\mathbf{H}_{3}$ : OP has a significant direct effect on $C S$.

\section{8. $O P$ and $C L$}

OP also has an factor in creating CL. Good OP will have an impact on building CL. Previous studies found the effect of OP on CL (Khalifa, 2018). Based on the previous research, the third hypothesis developed in this study is:

$\mathbf{H}_{4}$ : OP has a significant direct effect on $C L$.

\section{9. $C S$ and $C L$}

Research on the relationship between CS and CL has been very much done by researchers. This concludes that CS and CL have a very complex relationship. Previous research related to CS and CL found consistent results, where CS is an antecedent of CL. CS has a significant direct effect on CL. Some previous research that supports this result (Kim Kim \& Hwang, 2020; Lombart \& Louis, 2014; Islam, 2021; Le \& Le, 2020; Otsetova, 2017; Pandey et al., 2020; Prasetyo et al., 2021). Based on the previous research, the seventh hypothesis developed in this study is:

H5: CS has a significant direct effect on CL.

Research models can be seen in Fig. 1. 


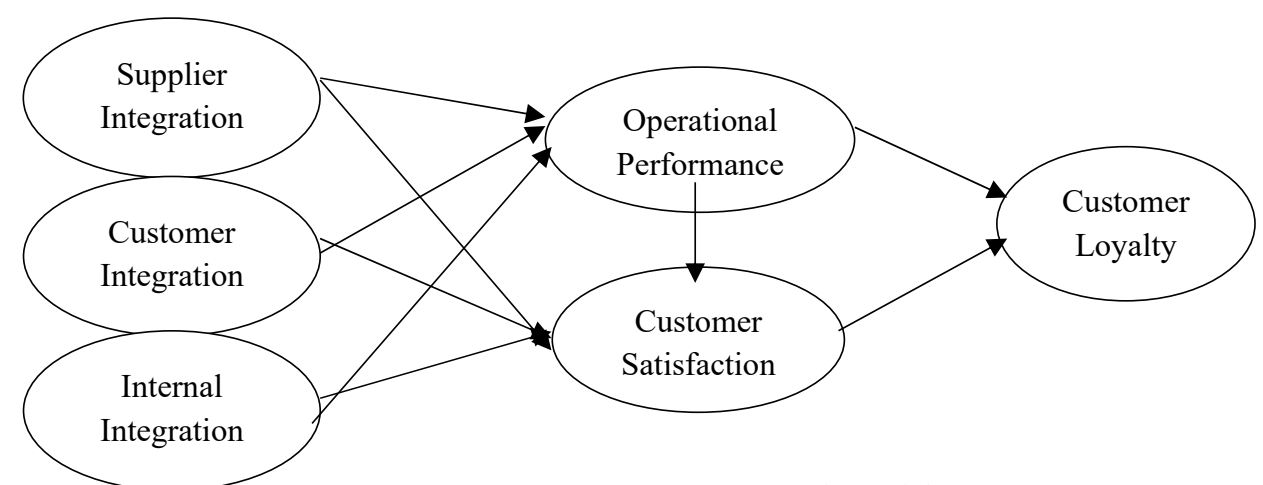

Fig. 1. Research Models

\section{Research Method}

\subsection{Data and Sample}

This study aims to test the effectSCI as supplier, customer, and internal integrity on CL. This study collects data from 308 Top Managers of Tuna Fillets SMEs Industries in Southeast Sulawesi Province, Indonesia as respondents. The characteristics of respondents can see Table 1. Data collection is done by using a questionnaire sent to respondents via Whatsapp with google form. The collected data was then analyzed using PLS-SEM.

Table 1

Respondents Characteristics

\begin{tabular}{llll} 
Characteristic & Classification & Frequency & Percentage \\
\hline Gender & Male & 238 & 77.27 \\
& Female & 70 & 22.73 \\
\hline Age & 20 to 29 & 52 & 16.89 \\
(in year) & 30 to 39 & 96 & 31.17 \\
& 40 to 49 & 83 & 26.94 \\
& 50 to 59 & 71 & 23.05 \\
& 60 or above & 6 & 1.95 \\
\hline Level of Education & High School & 177 & 57.47 \\
& Undergraduate & 121 & 39.28 \\
& Postgraduate & 10 & 3.25 \\
\hline District & Kendari & 212 & 68.83 \\
& Kolaka & 46 & 14.93 \\
& Baubau & 50 & 16.24 \\
\hline
\end{tabular}

Table 1 shows that gender characteristic, the most respondents were male $(77.27 \%)$, and age characteristic, the most respondents were aged 30-39 years (31.17\%). At the level of education, most respondents are high school education (57.47\%), most retailer districts are from Kendari $(68.833 \%)$.

\subsection{Measurements}

The variables in this research measured by Likert Scale. The indicators of the Supply Chain Integration (SCI) are developed by Zhao et al., 2013, namely; supplier integration ( 7 items), customer integration ( 6 items), and internal integration (6 items). Indicators of the OP, developed by Chavez et al., 2016, namely; production flexibility ( 3 items); delivery (3 items); product quality (3 item); and production cost (4 items). Indicators of the CS, developed by Liang, Choi \& Joppe, 2018, namely; transaction based satisfaction (3 items) and experience based satisfaction ( 3 items). Indicators of the CL, developed by Otsetova (2017), namely; behavioral loyalty ( 3 items) and attitudinal loyalty ( 3 items).

Reliability analysis was tested by Cronbach Alpha (CA) and factor loading (FL) with a value tolerance of 0.70 . Construct validity was measured using variance extracted (VE) with a value tolerance of 0.50 and composite reliability $(\mathrm{CR})$ with a value tolerance of 0.70 . 
Table 2

Latent and Observed Variables, Items, and Measurement

\begin{tabular}{|c|c|c|c|c|c|c|}
\hline $\begin{array}{c}\text { Latent } \\
\text { Variables }\end{array}$ & $\begin{array}{c}\text { Observed } \\
\text { Variables } \\
\end{array}$ & Item & FL & $\mathrm{CA}$ & $\mathrm{CR}$ & VE \\
\hline \multirow{19}{*}{$\begin{array}{c}\text { Supply Chain } \\
\text { Integration } \\
\text { (Zhao et al., 2013) }\end{array}$} & \multirow{7}{*}{$\begin{array}{c}\text { Supplier Integration } \\
\text { (SupInt) }\end{array}$} & SupInt 1 & 0.803 & \multirow[t]{7}{*}{0.792} & \multirow[t]{7}{*}{0.801} & \multirow[t]{7}{*}{0.784} \\
\hline & & SupInt 2 & 0.811 & & & \\
\hline & & SupInt 3 & 0.799 & & & \\
\hline & & SupInt 4 & 0.784 & & & \\
\hline & & SupInt 5 & 0.781 & & & \\
\hline & & SupInt 6 & 0.793 & & & \\
\hline & & SupInt 7 & 0.797 & & & \\
\hline & \multirow{6}{*}{$\begin{array}{l}\text { Customer Integration } \\
\text { (CusInt) }\end{array}$} & CusInt 1 & 0.836 & \multirow[t]{6}{*}{0.822} & \multirow[t]{6}{*}{0.844} & \multirow[t]{6}{*}{0.809} \\
\hline & & CusInt 2 & 0.841 & & & \\
\hline & & CusInt 3 & 0.819 & & & \\
\hline & & CusInt 4 & 0.820 & & & \\
\hline & & CusInt 5 & 0.825 & & & \\
\hline & & CusInt 6 & 0.822 & & & \\
\hline & \multirow{6}{*}{$\begin{array}{l}\text { Internal Integration } \\
\text { (InterInt) }\end{array}$} & InterInt 1 & 0.810 & \multirow[t]{6}{*}{0.793} & \multirow[t]{6}{*}{0.805} & \multirow[t]{6}{*}{0.776} \\
\hline & & InterInt 2 & 0.794 & & & \\
\hline & & InterInt 3 & 0.788 & & & \\
\hline & & InterInt 4 & 0.798 & & & \\
\hline & & InterInt 5 & 0.754 & & & \\
\hline & & InterInt 6 & 0.775 & & & \\
\hline \multirow{13}{*}{$\begin{array}{c}\text { Operational } \\
\text { Performance } \\
\text { (Chavez et al., } \\
\text { 2016) }\end{array}$} & \multirow{3}{*}{$\begin{array}{l}\text { Production Flexibility } \\
\text { (ProdFlex) }\end{array}$} & ProdFlex 1 & 0.836 & \multirow[t]{3}{*}{0.840} & \multirow[t]{3}{*}{0.847} & \multirow[t]{3}{*}{0.805} \\
\hline & & ProdFlex 2 & 0.845 & & & \\
\hline & & ProdFlex 3 & 0.853 & & & \\
\hline & \multirow{3}{*}{$\begin{array}{l}\text { Delivery } \\
\text { (Del) }\end{array}$} & Del 1 & 0.818 & \multirow[t]{3}{*}{0.821} & \multirow[t]{3}{*}{0.838} & \multirow[t]{3}{*}{0.809} \\
\hline & & Del 2 & 0.829 & & & \\
\hline & & Del 3 & 0.813 & & & \\
\hline & \multirow{3}{*}{$\begin{array}{l}\text { Product Quality } \\
\text { (ProQual) }\end{array}$} & ProQual 1 & 0.802 & 0.804 & 0.807 & 0.798 \\
\hline & & ProQual 2 & 0.806 & & & \\
\hline & & ProQual 3 & 0.807 & & & \\
\hline & Production Cost & ProCost 1 & 0.797 & 0.792 & 0.796 & 0.789 \\
\hline & (ProCost) & ProCost 2 & 0.795 & & & \\
\hline & & ProCost 3 & 0.790 & & & \\
\hline & & ProCost 4 & 0.793 & & & \\
\hline Satisfaction & Transaction & TranSat 1 & 0.772 & 0.754 & 0.766 & 0.726 \\
\hline (Liang, Choi \& & Satisfaction & TranSat 2 & 0.763 & & & \\
\hline Joppe, 2018) & (TranSat) & TranSat 3 & 0.728 & & & \\
\hline & Experience Satisfaction & ExSat 1 & 0.742 & 0.733 & 0.758 & 0.718 \\
\hline & (ExSat) & ExSat 2 & 0.751 & & & \\
\hline & & ExSat 3 & 0.768 & & & \\
\hline Loyalty & Behavioral & BehavLoy 1 & 0.883 & 0.841 & 0.856 & 0.827 \\
\hline (Otsetova, 2017) & (BehavLoy) & BehavLoy 2 & 0.826 & & & \\
\hline & & BehavLoy 3 & 0.839 & & & \\
\hline & Attitudinal & AttLoy 1 & 0.811 & 0.836 & 0.847 & 0.803 \\
\hline & (AttLoy) & AttLoy 2 & 0.824 & & & \\
\hline & & AttLoy 3 & 0.841 & & & \\
\hline
\end{tabular}

The testing results in Table 2 show that all of the research constructs used in this research have met the tolerance value limits.

\section{Result and Findings}

The results of the analysis of hypothesis testing 1a indicate that SupInt has a significant direct effect on $O P$ with the weight $=$ 0.754 ; t-test $=35.04$; and level of significance $=0.00 * * *$. The value of $=0.754$ indicates that SupInt affects $O P$ by $75.4 \%$, and t-test $=35.04$; and level of significance $=0.00 * * *$ interpreted that there is a significant effect SupInt on OP, thus it can be concluded that hypothesis $1 \mathrm{a}$ in this study is accepted. Hypothesis testing $1 \mathrm{~b}$ indicates that CusInt has a significant direct effect on $O P$ with the weight $=0.712$; t-test $=33.65$; and level of significance $=0.00 * * *$. The value of $=0.712$ indicates that CusInt affects $O P$ by $71.2 \%$, and t-test $=33.65$; and level of significance $=0.00 * * *$ interpreted that there is a significant effect CusInt on $O P$, thus it can be concluded that hypothesis $1 \mathrm{~b}$ in this study is accepted. The next, hypothesis testing $1 \mathrm{c}$ indicate 
that InterInt has a significant direct effect on $O P$ with the weight $=0.709$; t-test $=31.77$; and level of significance $=0.00^{* * *}$. The value of $=0.709$ indicates that InterInt affects $O P$ by $70.9 \%$, and t-test $=31.77$; and level of significance $=0.00 * * *$ interpreted that there is a significant effect InterInt on $O P$, thus it can be concluded that hypothesis $1 \mathrm{c}$ in this study is accepted. Based on the results of hypothesis testing 1a, 1b, and 1c it can be concluded that overall, SCI which consists of; suppliers, customers, and internal integration have a significant direct effect on $O P$.

The next hypothesis testing is the influence of SCI which consists of, supplier, customer, and internal integration to CS. The results of hypothesis testing $2 \mathrm{a}$ which states that SupInt has a significant direct effect on $C S$ shows that the weight $=0.443$; $\mathrm{t}-$ test $=27.83$; and level of significance $=0.00 * * *$. These results interpreted that SupInt influences $C S$ of $44.3 \%$, and the t-test $=27.83$; and level of significance $=0.00 * * *$ interpreted that there is a significant effect SupInt on CS, thus it can be concluded that hypothesis $2 \mathrm{a}$ in this study is accepted. And then, hypothesis testing $2 \mathrm{~b}$ which states that CusInt has a significant direct effect on $C S$ shows that the value of weight $=0.379$; t-test $=20.45$; and level of significance $=0.00009$. These results interpreted that CusInt influences $C S$ of $37.9 \%$, and the t-test $=20.45$; and level of significance $=0.00009$ interpreted that there is a significant effect CusInt on CS, thus it can be concluded that hypothesis $2 \mathrm{~b}$ in this study is accepted. Next, hypothesis testing 2c which states that InterInt has a significant direct effect on $C S$ shows that the value of weight $=0.432$; t-test $=25.39$; and level of significance $=0.00^{* * *}$. These results interpreted that InterInt influences $C S$ of $43.2 \%$, and the t-test $=25.39$; and level of significance $=0.00^{* * *}$ interpreted that there is a significant effect InterInt on $C S$, thus it can be concluded that hypothesis $2 \mathrm{c}$ in this study is accepted. Based on the results of hypothesis testing $2 \mathrm{a}, 2 \mathrm{~b}$, and $2 \mathrm{c}$ it can be concluded that overall, SCI which consists of; suppliers, customers, and internal integration have a significant direct effect on $C S$.

The results of test the effect of $O P$ on $C S$ implies a significant effect with the weight $=0.557$; t-test $=29.83$; and level of significance $=0.00^{* * *}$. The value of $=0.557$ indicates that $O P$ affects $C S$ by $55.7 \%$, and the t-test $=33.65$; significance values $=0.00 * * *$ implies that there is a significant effect $O P$ on $C S$, thus it can be concluded that hypothesis 3 in this study is accepted. For the results of test the effect of $O P$ on $C L$ implies a significant effect of $O P$ on $C L$ with the weight $=0.562 ; \mathrm{t}-$ test $=30.03$; and level of significance $=0.00 * * *$. The value of $=0.562$ indicates that $O P$ affects $C L$ by $56.2 \%$, and the $\mathrm{t}$-test $=$ 21.77; significance values $=0.00016$ implies that there is a significant effect $O P$ on $C L$, thus it can be concluded that hypothesis 4 in this study is accepted. The last results test in these study is the effect of $C S$ on $C L$ implies a significant effect of $C S$ on $C L$ with the weight $=0.623$; t-test $=31.74$; and level of significance $=0.00 * * *$. The value of $=0.623$ indicates that $C S$ affects $C L$ by $62.3 \%$, and the t-test $=31.74$; significance values $=0.00 * * *$ implies that there is a significant effect $C S$ on $C L$, thus it can be concluded that hypothesis 5 in this study is accepted.

The results of testing the research model also show that there is an indirect effect on $S C I$ which consists of; supplier, customer, and internal integration towards $C S$ through $O P$, with the indirect coefficient being; SupInt $=0.419 ;$ CusInt $=0.395$; and InterInt $=0.394$. These results imply that $O P$ is able to mediate the influence of $S C I$ on $C S$. In addition, the results of testing the research model also obtained information that the $S C I$ which consists of; suppliers, customers, and internal integration have an indirect influence on $C L$ through $O P$, with an indirect coefficient of each; SupInt $=0.424$; CusInt $=0.400$; and InterInt $=0.398$. These results provide information that $O P$ can act as a mediator of the influence of $S C I$ on $C L$.

The results of testing this research model also obtained information that there is an indirect effect on SCI which consists of; suppliers, customers, and internal integration towards $C L$ through $C S$, with indirect coefficients of respectively; SupInt $=$ 0.276; CusInt $=0.236$; and InterInt $=0.269$. These results imply that $C S$ can act as a mediator of the influence of $S C I$ on $C L$. In addition, based on the results of testing the research model, information was also obtained that there was an indirect effect of $O P$ on $C L$ through $C S$ with the indirect coefficient being 0.347 . These results imply that $C S$ can act as a mediator of the influence of $O P$ on $C L$. The overall results of testing the research model can be seen in Table 3 .

Table 3

\begin{tabular}{|c|c|c|c|c|c|c|}
\hline \multirow[t]{2}{*}{ Hypothesis } & \multirow[t]{2}{*}{ Relationship } & \multirow[t]{2}{*}{ Weight } & \multirow[t]{2}{*}{$t$-test } & \multirow{2}{*}{$\begin{array}{c}\text { Significance } \\
\text { Value }\end{array}$} & \multicolumn{2}{|c|}{ Indirect Effect } \\
\hline & & & & & Weight & Sig. \\
\hline H1a & SupInt $-O P$ & 0.754 & 35.04 & $0.00 * * *$ & - & - \\
\hline $\mathrm{H} 1 \mathrm{~b}$ & CusInt $-O P$ & 0.712 & 33.65 & $0.00 * * *$ & - & - \\
\hline $\mathrm{H} 1 \mathrm{c}$ & InterInt $-O P$ & 0.709 & 31.77 & $0.00 * * *$ & - & - \\
\hline $\mathrm{H} 2 \mathrm{a}$ & SupInt $-C S$ & 0.443 & 27.83 & $0.00 * * *$ & 0.419 & $0.00 * * *$ \\
\hline $\mathrm{H} 2 \mathrm{~b}$ & CusInt - CS & 0.379 & 20.45 & 0.00009 & 0.395 & 0.00004 \\
\hline $\mathrm{H} 2 \mathrm{c}$ & InterInt $-C S$ & 0.432 & 25.39 & $0.00 * * *$ & 0.394 & 0.00005 \\
\hline $\mathrm{H} 3$ & $O P-C S$ & 0.557 & 29.83 & $0.00 * * *$ & - & - \\
\hline H4 & $\mathrm{OP}-\mathrm{CL}$ & 0.562 & 30.03 & $0.00 * * *$ & 0.347 & 0.00019 \\
\hline $\mathrm{H} 5$ & $C S-C L$ & 0.623 & 31.74 & $0.00 * * *$ & - & - \\
\hline \multicolumn{5}{|c|}{ SupInt $-O P-C L$} & 0.424 & $0.00 * * *$ \\
\hline \multicolumn{5}{|c|}{ CusInt $-O P-C L$} & 0.400 & $0.00 * * *$ \\
\hline \multicolumn{5}{|c|}{ InterInt $-O P-C L$} & 0.398 & 0.00001 \\
\hline \multicolumn{5}{|c|}{ SupInt $-C S-C L$} & 0.276 & 0.00020 \\
\hline \multicolumn{5}{|c|}{ CusInt $-C S-C L$} & 0.236 & 0.00047 \\
\hline \multicolumn{5}{|c|}{ InterInt $-C S-C L$} & 0.269 & 0.00035 \\
\hline & $\mathrm{R}^{2}$ (Loyalty) & 0.925 & & & & \\
\hline & Adj. R² (Loyalty) & 0.898 & & & & \\
\hline
\end{tabular}




\section{Discussion}

The research found that $S C I$, which consists of; suppliers, customers, and internal integration has a significant direct effect on $O P$. These results consist with the previous studies (Lu et al., 2018; Errassafi, Abbar \& Benabbou, 2019; Liu, Liu \& Gu, 2021; Hani, 2021; Nartey, Aboagye-Otchere \& Simpson, 2020; Wong, Boon-Itt \& Wong, 2011). Then, SCI, which consists of; suppliers, customers, and internal integration also has a significant direct effect on CS. These results are support of the previous studies (Yu et al., 2013; Zhao et al., 2013). This result implies that the perception of top managers of Tuna Fillets SMEs Industries in Southeast Sulawesi Province in Indonesia on the current Supply Chain Integration can directly improve operational performance and create their Customer Satisfaction. The test results also show that $O P$ has a significant direct effect on CS. These results are consistent with previous studies (Abdallah, Phan \& Matsui, 2016; Chavez et al., 2016). Then, $O P$ has a significant direct effect on $C L$. These results are consistent with previous studies (Khalifa, 2018). This implies that the increase in operational performance obtained by Tuna Fillets SMEs Industries in Southeast Sulawesi Province in Indonesia from the implementation of Supply Chain Integration will directly lead to the creation of customer satisfaction which in turn can build customer loyalty. This study also found that $C S$ has a significant effect on $C L$. This finding is in accordance with the findings of several previous studies (Kim Kim \& Hwang, 2020; Lombart \& Louis, 2014; Islam, 2021; Le \& Le, 2020; Otsetova, 2017; Pandey et al., 2020; Prasetyo et al., 2021). This result implies that the satisfaction felt by customers of Tuna Fillets SMEs Industries in Southeast Sulawesi Province in Indonesia will directly lead to the building of loyalty in their customers. The findings of the research that provide information that $O P$ and $C S$ can act as mediators of the influence of SCI on $C L$ imply that increasing operational performance and creating satisfaction for Tuna Fillets SMEs Industries in Southeast Sulawesi Province on Indonesia customers from the results of the implementation of supply chain integration, impact on building loyalty to Tuna Fillets SMEs Industries customers.

\section{Conclusion}

The objective of this research is to analyze the effect of Supply Chain Integration, which consists of; suppliers, customers, and internal integration on Customer Loyalty, where the operational performance and customer satisfaction are mediators of the causality. Data study collected from 308 top managers of Tuna Fillets SMEs Industries in Southeast Sulawesi Province in Indonesia. This research found that Supply Chain Integration, which consists of; suppliers, customers, and internal integration had a significant direct effect on operational performance and customer satisfaction. The research also found that operational performance and customer satisfaction have an impact on increasing loyalty of Tuna Fillets SMEs Industries customers. The results of the analysis also provide information that operational performance and customer satisfaction can be a mediator of the influence of Supply Chain Integration, which consists of; suppliers, customers, and internal integration to customer loyalty.

\section{Limitation and Implication of Future Research}

This research was conducted only limited to top managers of Tuna Fillets SMEs Industries in Southeast Sulawesi Province in Indonesia, so that future suggested to adoption to the other agribusiness manufactured industries. The research study also limited the use of supplier, customer, and internal as indicators of Supply Chain Integration. Future research is suggested to develop Supply Chain Integration indicators using External Integration.

\section{References}

Abdallah, A. B., Phan, A. C., \& Matsui, Y. (2016). Investigating the effects of managerial and technological innovations on operational performance and customer satisfaction of manufacturing companies. International Journal of Business Innovation and Research, 10(2-3), 153-183. https://doi.org/10.1504/IJBIR.2016.074824

Acar, M. F., Zaim, S., Isik, M., \& Calisir, F. (2017). Relationships among ERP, supply chain orientation and operational performance: An analysis of structural equation modeling. Benchmarking: An International Journal, 24(5), $1291-1308$. https://doi.org/10.1108/BIJ-11-2015-0116

Al-Sa'di, A. F., Abdallah, A. B., \& Dahiyat, S. E. (2017). The mediating role of product and process innovations on the relationship between knowledge management and operational performance in manufacturing companies in Jordan. Business Process Management Journal, 23(2), 349-376. https://doi.org/10.1108/BPMJ-03-2016-0047

Amoako-Gyampah, K., Boakye, K. G., Famiyeh, S., \& Adaku, E. (2020). Supplier integration, operational capability and firm performance: an investigation in an emerging economy environment. Production Planning \& Control, 31(13), 1128-1148. https://doi.org/10.1080/09537287.2019.1700570

Amoako, T., Sheng, Z. H., Dogbe, C. S. K., \& Pomegbe, W. W. K. (2020). Effect of internal integration on SMEs' performance: the role of external integration and ICT. International Journal of Productivity and Performance Management. https://doi.org/10.1108/IJPPM-03-2020-0120

Ariadi, G., Surachman, Sumiati, \& Rohman, F. (2021). The effect of lean and agile supply chain strategy on financial performance with mediating of strategic supplier integration \& strategic customer integration: Evidence from bottled drinking-water industry in Indonesia. Cogent Business \& Management, 8(1), 1930500. https://doi.org/10.1080/23311975.2021.1930500 
Arthatiani, F. Y., Suryawati, S. H., Luhur, E. S., \& Kurniawan, T. (2020). ANALISIS STRUKTUR, PERILAKU DAN KINERJA PASAR INDUSTRI TUNA DI INDONESIA. Jurnal Sosial Ekonomi Kelautan dan Perikanan, 15(1), 69-82. http://dx.doi.org/10.15578/jsekp.v15i1.8343

Buzzetto, R. R., Bauli, M. R., \& Carvalho, M. M. D. (2020). The key aspects of procurement in project management: investigating the effects of selection criteria, supplier integration and dynamics of acquisitions. Production, 30. https://doi.org/10.1590/0103-6513.20190112

Chavez, R., Yu, W., Feng, M., \& Wiengarten, F. (2016). The effect of customer-centric green supply chain management on operational performance and customer satisfaction. Business Strategy and the Environment, 25(3), 205-220. https://doi.org/10.1002/bse.1868

De Vass, T., Shee, H., \& Miah, S. J. (2018). The effect of "Internet of Things" on supply chain integration and performance: An organisational capability perspective. Australasian Journal of Information Systems, 22. https://doi.org/10.3127/ajis.v22i0.1734

dos Santos Hentschke, C., Torres Formoso, C., \& Echeveste, M. E. (2020). A customer integration framework for the development of mass customised housing projects. Sustainability, 12(21), 8901. https://doi.org/10.3390/su12218901

Errassafi, M., Abbar, H., \& Benabbou, Z. (2019). The mediating effect of internal integration on the relationship between supply chain integration and operational performance: Evidence from Moroccan manufacturing companies. Journal of Industrial Engineering and Management, 12(2), 254-273. http://dx.doi.org/10.3926/jiem.2794

Ganbold, O., Matsui, Y., \& Rotaru, K. (2020). Effect of information technology-enabled supply chain integration on firm's operational performance. Journal of Enterprise Information Management, 34(3), 948-989. https://doi.org/10.1108/JEIM$\underline{10-2019-0332}$

Hani, J. (2021). The moderating role of lean operations between supply chain integration and operational performance in Saudi manufacturing organizations. Uncertain Supply Chain Management, 9(1), 169-178. 10.5267/j.uscm.2020.10.004

Islam, T., Islam, R., Pitafi, A. H., Xiaobei, L., Rehmani, M., Irfan, M., \& Mubarak, M. S. (2021). The impact of corporate social responsibility on customer loyalty: The mediating role of corporate reputation, customer satisfaction, and trust. Sustainable Production and Consumption, 25, 123-135. https://doi.org/10.1016/j.spc.2020.07.019

Jajja, M. S. S., Chatha, K. A., \& Farooq, S. (2018). Impact of supply chain risk on agility performance: Mediating role of supply chain integration. International Journal of Production Economics, 205, 118-138. https://doi.org/10.1016/j.ijpe.2018.08.032

Ji, C., \& Prentice, C. (2021). Linking transaction-specific satisfaction and customer loyalty-the case of casino resorts. Journal of Retailing and Consumer Services, 58, 102319. https://doi.org/10.1016/i.jretconser.2020.102319

Jung, H. K., \& Boo, J. (2020). A Study on the Effect of Customer Integration and Market Orientation on the Uncertainty and Flexibility of Supply Chain and Management. Journal of the Society of Korea Industrial and Systems Engineering, 43(4), 178-189. https://doi.org/10.11627/jkise.2020.43.4.178

Khalaf, M. A., \& El Mokadem, M. Y. (2019). The relationship between internal integration and manufacturing flexibility in the Egyptian industry. International Journal of Quality and Service Sciences, 11(1), 16-33. https://doi.org/10.1108/IJQSS$\underline{06-2017-0052}$

Khalifa, G. (2018). The Egyptian Hotels, where in the competitive environment? competitive strategies and market orientation and its impact on customer loyalty: The mediating role of operational performance. International Journal of Management and Human Science (IJMHS), 2(4), 60-72. https://ejournal.lucp.net/index.php/ijmhs/article/view/810/730

Kim, W., Kim, H., \& Hwang, J. (2020). Sustainable growth for the self-employed in the retail industry based on customer equity, customer satisfaction, and loyalty. Journal of Retailing and Consumer Services, 53, 101963. https://doi.org/10.1016/j.jretconser.2019.101963

Kurnia, M., \& Mallawa, A. (2021). Operational Performance Of PPI Paotere Makassar City. Torani Journal of Fisheries and Marine Science, 110-124. https://doi.org/10.35911/torani.v4i2.14078

LE, H. B. H., \& LE, T. B. (2020). Impact of Destination Image and Satisfaction on Tourist Loyalty: Mountain Destinations in Thanh Hoa Province, Vietnam. The Journal of Asian Finance, Economics and Business, 7(4), 185-195. https://doi.org/10.13106/JAFEB.2020.VOL7.NO4.185

Liang, L. J., Choi, H. C., \& Joppe, M. (2018). Exploring the relationship between satisfaction, trust and switching intention, repurchase intention in the context of Airbnb. International Journal of Hospitality Management, 69, 41-48. https://doi.org/10.1016/j.ijhm.2017.10.015

Liu, A., Liu, H., \& Gu, J. (2021). Linking business model design and operational performance: The mediating role of supply chain integration. Industrial Marketing Management, 96, 60-70. https://doi.org/10.1016/j.indmarman.2021.04.009

Lombart, C., \& Louis, D. (2014). A study of the impact of Corporate Social Responsibility and price image on retailer personality and consumers' reactions (satisfaction, trust and loyalty to the retailer). Journal of Retailing and Consumer services, 21(4), 630-642. https://doi.org/10.1016/j.jretconser.2013.11.009

Lu, D., Ding, Y., Asian, S., \& Paul, S. K. (2018). From supply chain integration to operational performance: The moderating effect of market uncertainty. Global Journal of Flexible Systems Management, 19(1), 3-20. https://doi.org/10.1007/s40171-017-0161-9

Martinelli, E. M., \& Tunisini, A. (2019). Customer integration into supply chains: literature review and research propositions. Journal of Business \& Industrial Marketing, 34(1), 24-38. https://doi.org/10.1108/JBIM-07-2017-0162 
Munir, M., Jajja, M. S. S., Chatha, K. A., \& Farooq, S. (2020). Supply chain risk management and operational performance: The enabling role of supply chain integration. International Journal of Production Economics, $227,107667$. https://doi.org/10.1016/j.ijpe.2020.107667

Nartey, E., Aboagye-Otchere, F. K., \& Simpson, S. N. Y. (2020). The contingency effects of supply chain integration on management control system design and operational performance of hospitals in Ghana. Journal of Accounting in Emerging Economies, 10(20), 207-241. https://doi.org/10.1108/JAEE-10-2018-0111

Nunkoo, R., Teeroovengadum, V., Ringle, C. M., \& Sunnassee, V. (2020). Service quality and customer satisfaction: The moderating effects of hotel star rating. International Journal of Hospitality Management, 91, 102414. https://doi.org/10.1016/j.ijhm.2019.102414

Otsetova, A. (2017). Relationship Between Logistics Service Quality, Customer Satisfaction and Loyalty in Courier Services Industry. Management \& Education/Upravlenie i Obrazovanie, 13.

PAAIS, M., \& PATTIRUHU, J. R. (2020). Effect of Motivation, Leadership, and Organizational Culture on Satisfaction and Employee Performance. The Journal of Asian Finance, Economics and Business, 7(8), 577-588. https://doi.org/10.13106/JAFEB.2020.VOL7.NO8.577

Pakiding, F., \& Silamba, I. (2018). Perencanaan Pengembangan Industri Skala Kecil Fillet Ikan Tuna (Tunnus sp) di Kabupaten Manokwari. Agritechnology, 1(2), 84-93. https://doi.org/10.51310/agritechnology.v1i2.21

Pandey, N., Tripathi, A., Jain, D., \& Roy, S. (2020). Does price tolerance depend upon the type of product in e-retailing? Role of customer satisfaction, trust, loyalty, and perceived value. Journal of Strategic Marketing, $28(6), 522-541$. https://doi.org/10.1080/0965254X.2019.1569109

Phan, T., Doan, X., \& Nguyen, T. (2020). The impact of supply chain practices on performance through supply chain integration in textile and garment industry of Vietnam. Uncertain Supply Chain Management, 8(1), 175-186. 10.5267/j.uscm.2019.7.006

Prasetyo, Y. T., Tanto, H., Mariyanto, M., Hanjaya, C., Young, M. N., Persada, S. F., ... \& Redi, A. A. N. P. (2021). Factors affecting customer satisfaction and loyalty in online food delivery service during the covid-19 pandemic: Its relation with open innovation. Journal of Open Innovation: Technology, Market, and Complexity, 7(1), 76. https://doi.org/10.3390/joitmc7010076

Prayoga, M. Y., Iskandar, B. H., \& Wisudo, S. H. (2017). Peningkatan kinerja manajemen rantai pasok tuna segar di PPS Nizam Zachman Jakarta (PPSNZJ). ALBACORE Jurnal Penelitian Perikanan Laut, 1(1), $77-88$. https://doi.org/10.29244/core.1.1.77-88

Salam, M. A. (2017). The mediating role of supply chain collaboration on the relationship between technology, trust and operational performance: An empirical investigation. Benchmarking: An International Journal, 24(2), 298-317. https://doi.org/10.1108/BIJ-07-2015-0075

Saragih, J., Tarigan, A., Silalahi, E. F., Wardati, J., \& Pratama, I. (2020). Supply Chain Operational Capability and Supply Chain Operational Performance: Does the Supply Chain Management and Supply Chain Integration Matters. International Journal of Supply Chain Management, 9(4), 1222.

Shou, Y., Li, Y., Park, Y., \& Kang, M. (2018). Supply chain integration and operational performance: the contingency effects of production systems. Journal of Purchasing and Supply Management, 24(4), 352-360. https://doi.org/10.1016/j.pursup.2017.11.004

Shukor, A. A. A., Newaz, M. S., Rahman, M. K., \& Taha, A. Z. (2020). Supply chain integration and its impact on supply chain agility and organizational flexibility in manufacturing firms. International Journal of Emerging Markets. https://doi.org/10.1108/IJOEM-04-2020-0418

Tarigan, Z., Mochtar, J., Basana, S., \& Siagian, H. (2021). The effect of competency management on organizational performance through supply chain integration and quality. Uncertain Supply Chain Management, 9(2), $283-294$. 10.5267/j.uscm.2021.3.004

Truong, H. Q., Sameiro, M., Fernandes, A. C., Sampaio, P., Duong, B. A. T., Duong, H. H., \& Vilhenac, E. (2017). Supply chain management practices and firms' operational performance. International Journal of Quality \& Reliability Management, 34(2), 176-193. https://doi.org/10.1108/IJQRM-05-2015-0072

Wong, C. Y., Boon-Itt, S., \& Wong, C. W. (2011). The contingency effects of environmental uncertainty on the relationship between supply chain integration and operational performance. Journal of Operations management, 29(6), 604-615. https://doi.org/10.1016/i.jom.2011.01.003

Yu, W., Jacobs, M. A., Salisbury, W. D., \& Enns, H. (2013). The effects of supply chain integration on customer satisfaction and financial performance: An organizational learning perspective. International Journal of Production Economics, 146(1), 346-358. https://doi.org/10.1016/i.ijpe.2013.07.023

Zhang, Q., Pan, J., Jiang, Y., \& Feng, T. (2020). The impact of green supplier integration on firm performance: The mediating role of social capital accumulation. Journal of Purchasing and Supply Management, $26(2), 100579$. https://doi.org/10.1016/j.pursup.2019.100579

Zhao, L., Huo, B., Sun, L., \& Zhao, X. (2013). The impact of supply chain risk on supply chain integration and company performance: a global investigation. Supply Chain Management: An International Journal, 18(2), 115-131. https://doi.org/10.1108/13598541311318773 
(C) 2021 by the authors; licensee Growing Science, Canada. This is an open access article distributed under the terms and conditions of the Creative Commons Attribution (CCBY) license (http://creativecommons.org/licenses/by/4.0/). 